\title{
Detection of Myxobolus rotundus (Myxozoa: Myxosporea) in skin mucus of crucian carp Carassius auratus auratus using a monoclonal antibody
}

\author{
Y. S. Lu, P. Nie* , B. J. Sun \\ State Key Laboratory of Freshwater Ecology and Biotechnology and Laboratory of Fish Diseases, Institute of Hydrobiology, Chinese Academy \\ of Sciences, Wuhan 430072, Hubei Province, PR China
}

\begin{abstract}
Diagnosis of myxosporean Myxobolus rotundus infection was conducted by examining skin mucus from the infected crucian carp Carassius auratus auratus with a monoclonal antibody, MAb 2D12, raised previously against the parasite. A positive reaction was observed in skin mucus collected from infected fish, and spores and pre-spore stages of the parasite were identified by the MAb 2D12. It was also demonstrated that $M$. rotundus infection can be successfully detected by a simple method, enzyme-linked immunosorbent assay (ELISA), and that skin mucus collected from infected fish skin had a significantly higher optical density (OD) value than that from uninfected fish.
\end{abstract}

KEY WORDS: Myxosporean $\cdot$ Myxobolus rotundus $\cdot$ Crucian carp - Carassius auratus auratus · Skin mucus · Monoclonal antibody $\cdot$ Diagnosis

Resale or republication not permitted without written consent of the publisher

Diagnoses of myxosporean infections are normally confirmed by their spores and/or pre-spore stages being in evidence (Hedrick et al. 1992, Thoesen 1994). To detect spores, a pepsin-trypsin digestion method can be employed to release spores from host tissues (Markiw \& Wolf 1974). Recently, molecular techniques have been used to detect myxosporean infections and even to identify their species. Andree et al. (1998) developed a nested polymerase chain reaction (PCR) for the detection of genomic DNA of Myxobolus cerebralis, and Antonio et al. (1988) identified the myxosporean infection in fish and in its oligochaete hosts by using non-radioactive in situ hybridization. Baldwin \& Myklebust (2002) used a single round PCR for the identification of $M$. cerebralis myxospores. Antisera have also been employed to detect myxosporeans (Markiw \& Wolf 1978, Hamilton \& Canning 1988, Markiw 1989), although cross-reactions cannot always be avoided. A monoclonal antibody of high specificity was therefore developed to identify the developmental and sporogonic stages of the proliferative kidney disease pathogen, which is now known as a myxosporean infection (Marin de Mateo et al. 1993).

Myxobolus rotundus (Nemezek, 1911), a common myxosporean parasite of China's major cultured cyprinid, the crucian carp Carassius auratus auratus (L.), is known to cause severe myxosporadiosis in fish (Wu \& Wang 2000). Although mortalities have seldom been reported, the market value of infected fish is seriously reduced due to large visible cysts on the body surface (Lu et al. 2002). Early, accurate detection of this infection is crucial, therefore, for its prevention and treatment. In a previous study, Lu et al. (2002) developed a monoclonal antibody, MAb 2D12, which reacts specifically with both trophozoites and spores of $M$. rotundus. The present study was thus conducted to determine whether a myxosporean infection could be diagnosed by examining fish skin mucus with MAb 2D12.

Six specimens of crucian carp Carassius auratus auratus with visible cysts of Myxobolus rotundus were obtained from a fish farm in Wuhan, Hubei Province, China, and 2 non-infected fish from another Wuhan farm, with no recorded myxosporean infection. The absence of the parasite was confirmed by microscopic examination, as follows. The fish skin mucus was scraped gently with a glass slide, then pooled, before being stored at $4^{\circ} \mathrm{C}$ for not longer than $12 \mathrm{~h}$, in order to avoid the destruction of pre-spore stages. The MAb 2D12 raised against $M$. rotundus was used in the study. The dot immunobinding assay was carried out according to Hawkes et al. (1982). Briefly, the diluted mucus $(1: 10)$ was spotted onto a nitrocellulose membrane 


$\left(\begin{array}{llllll}0 & 0 & 0 & 0 & 0 & \\ 1 & 2 & 3 & 4 & 5 & 6\end{array}\right.$

Fig. 1. Carassius auratus auratus. Reaction of skin mucus with MAb 2D12, as determined by dot immunobinding assay. Dot 1: soluble antigens of Myxobolus rotundus as positive control; Dots 2 to 5: skin mucus of 4 infected fish; Dot 6: uninfected fish skin mucus

(0.45 $\mu \mathrm{m}$, Sigma), before being washed 3 times in a petri dish by PBST (PBS pH 7.4 with $0.05 \%$ Tween-20). Adding $5 \mathrm{ml} 3 \%$ skimmed milk for $30 \mathrm{~min}$ at $37^{\circ} \mathrm{C}$ blocked non-specific binding sites. The membrane was probed with the MAb 2D12 (1:2000 in PBST), peroxidase-labelled goat-anti-mouse serum (1:1000 in PBST, Biotech), and colour-developed with diaminobenzidine $(\mathrm{SABC})$. The indirect fluorescent antibody technique (IFAT) as described by Anderson (1990) was also employed to detect the parasite in the skin mucus, but with the following modification: slides with dried mucus smears were fixed in $10 \%(\mathrm{v} / \mathrm{v})$ methanol for 20 min before being rinsed 3 times in PBS ( $\mathrm{pH}$ 8.0). MAb 2D12 (1:10000 in PBST) and fluorescein isothiocyanate-labelled goat-anti-mouse serum $(1: 1000$ in PBST, SABC) were then added to the smear and incubated at $37^{\circ} \mathrm{C}$. Lastly, the smears were examined under a fluorescent microscope.

The sensitivity of MAb 2D12 was further tested by an indirect enzyme-linked immunosorbent assay (ELISA). The fish mucus was serially diluted and each dilution added to a separate well for coating micro titration plates (Nunc). PBS ( $\mathrm{pH} 7.6$ ) was used for blank controls. The dilution of the MAb 2D12 and peroxidase-labelled goat-anti-mouse serum was optimized, and 1:10000 and 1:1000 in PBST used, respectively. O-phenylenediamine was added as chromogenic substrate following the manufacturer's instructions (Sigma). The optical density was immediately measured at $492 \mathrm{~nm}$ with a plate reader, and analyzed with a 1-way ANOVA.

As shown in Fig. 1, MAb 2D12 reacted with the skin mucus collected from Myxobolus rotundus-infected cru-
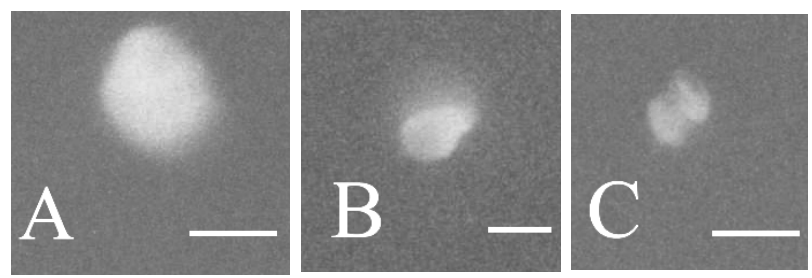

Fig. 2. Carassius auratus auratus. Identification of (A) trophozoite, (B) disporous stage and (C) spore of Myxobolus rotundus in the infected skin mucus by means of the indirect fluorescent antibody technique (IFAT) using MAb 2D12. Scale bars $=10 \mu \mathrm{m}$ cian carp, but not with mucus from non-infected fish. Using IFAT, it was also demonstrated that pre-spore stages, including trophozoite, the disporous stage, and spores of $M$. rotundus can be identified in the skin mucus of the infected fish by using MAb 2D12 (Fig. 2). ELISA analyses revealed that skin mucus from infected fish had significantly higher optical density (OD) values than that of uninfected fish, even when the skin mucus was diluted $\times 5120(F=2254.07, \mathrm{p}<0.05)$ (Fig. 3).

The present study has for the first time demonstrated the successful application of a monoclonal antibody in the detection of myxosporean infections by examining fish skin mucus. This seems to be a very effective tool for diagnosing myxosporean infection, and the use of a monoclonal antibody can even ensure the specific identification of myxosporeans at species level (Lu et al. 2002). The identification of pre-spore and spore stages of Myxobolus rotundus in skin mucus may, to a large extent, indicate that the antigens recognized by MAb 2D12 are not excretory and/or secretory. However, as the infected fish used in the present study already had

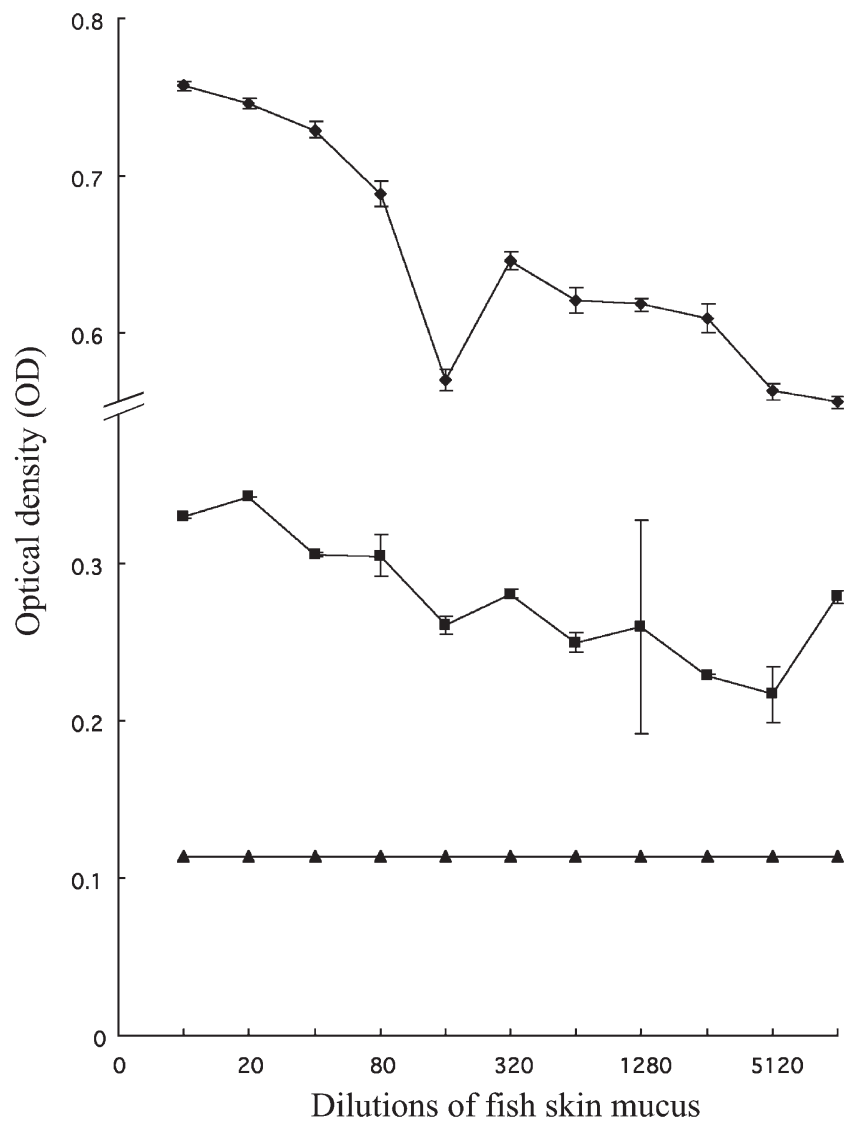

Fig. 3. Carassius auratus auratus. Response of skin mucus from infected $(\bullet)$ ) and uninfected (ロ- - ) fish to MAb 2D12 by means of enzyme-linked immunosorbent assay (ELISA). Bottom line $(\boldsymbol{\Lambda}-\mathbf{\Lambda})$ indicates blank control, and bars represent SD 
visible cysts on the body surface and were therefore at a later stage of infection, it remains unknown whether earlier stages of myxosporean infection could be detected by examining fish skin mucus. It would also be of significance to establish whether the parasite in its oligochaete hosts could be detected with MAb 2D12.

Acknowledgements. The study was supported by funds awarded to P. Nie by the knowledge innovation program of the Chinese Academy of Sciences (No. KSCX2-1-04), and by the National Natural Science Foundation of China (30025035, 30130150).

\section{LITERATURE CITED}

Anderson DP (1990) Fluorescent antibody test. In: Stolen JS, Fletcher TC, Anderson DP, Robertson BS, van Willem B (eds) Techniques in fish immunology, 1st edn. SOS Publications, Fair Haven, NJ, p 1-8

Andree KB, MacConnell E, Hedrick RP (1998) A nested polymerase chain reaction for the detection of genomic DNA of Myxobolus cerebralis in rainbow trout, Oncorhynchus mykiss. Dis Aquat Org 34:145-154

Antonio DB, Andree KB, McDowell TS, Hedrick RP (1988) Detection of Myxobolus cerebralis in rainbow trout and oligochaete tissues by using a non-radioactive in situ hybridization (ISH) protocol. J Aquat Anim Health 10: 338-347

Baldwin TJ, Myklebust KA (2002) Validation of a single round polymerase chain reaction assay for identification of Myxobolus cerebralis myxospores. Dis Aquat Org 49: 180-190

Hamilton AJ, Canning EU (1988) The production of mouse anti-Myxosoma cerebralis antiserum from Percoll ${ }^{\circledR}$-puri-

Editorial responsibility: Wolfgang Körting,

Hannover, Germany fied spores and its use in immunofluorescent labelling of Historesin ${ }^{\circledR}$-embedded cartilage derived from infected rainbow trout, Salmo gairdneri Richardson. J Fish Dis 11: $185-190$

Hawkes R, Niday E, Gordon J (1982) A dot-immunobinding assay for monoclonal and other antibodies. Anal Biochem 119:142-147

Hedrick RP, Marin M, Castagnaro M, Monge M, de Kinkelin $P$ (1992) A rapid lectin-based staining procedure for the detection of the myxosporean causing proliferative kidney disease. Dis Aquat Org 13:129-132

Lu YS, Li M, Wu YS, Wang JG (2002) Antigenic study of Myxobolus rotundus (Myxozoa: Myxosporea) using monoclonal antibodies. J Fish Dis 25:307-310

Marin de Mateo M, Adams A, Richards RH, Castagnaro M, Hedrick RP (1993) Monoclonal antibody and lectin probes recognize developmental and sporogonic stages of PKX, the causing agent of proliferative kidney disease (PKD) from European and North American salmonid fish. Dis Aquat Org 15:57-63

Markiw ME (1989) Salmonid whirling disease: myxosporean and actinosporean stages cross-react in direct fluorescent antibody test. J Fish Dis 12:137-141

Markiw ME, Wolf K (1974) Myxosoma cerebralis: isolation and concentration from fish skeletal elements-sequential enzymatic digestions and purification by differential centrifugation. J Fish Res Board Can 31:15-20

Markiw ME, Wolf K (1978) Myxosoma cerebralis: fluorescent antibody techniques for antigen recognition. J Fish Res Board Can 35:828-832

Thoesen JC (1994) Suggested procedures for the detection and identification of certain finfish and shellfish pathogens, 4th edn, Version 1. Fish Health Section, American Fisheries Society, Bethesda, MD

Wu YS, Wang JG (2000) The immunogenicity of Myxobolus rotundus Nemeczek, 1911. Acta Hydrobiol Sin 24: $246-251$

Submitted: September 15, 2002; Accepted: December 4, 2002 Proofs received from author(s): March 3, 2003 